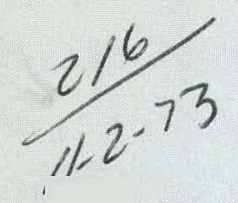
\title{
MASTER,
}

Y-1923

\section{LENGTH AND STRAIN-RATE EFFECTS ON THE PROBABILITY OF FAILURE OF TWO BORON REINFORCING MONOFILAMENTS}

R. E. Oakes, Jr

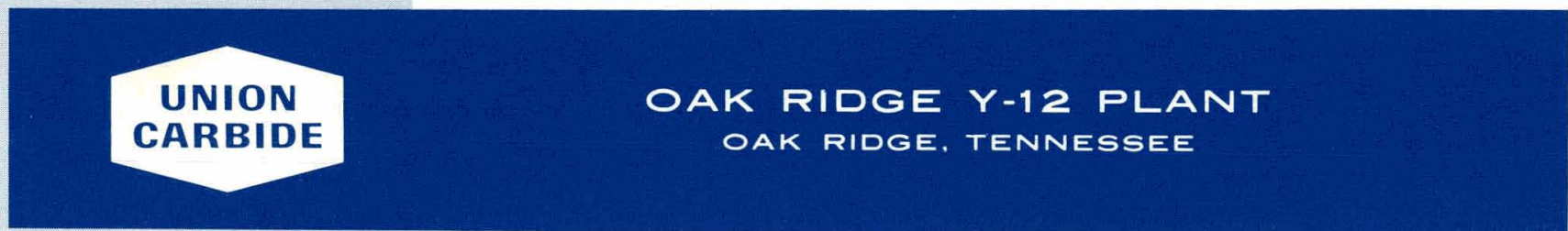

prepared for the U.S. ATOMIC ENERGY COMMISSION

under U.S. GOVERNMENT Contract W.7405 eng 26 


\section{DISCLAIMER}

This report was prepared as an account of work sponsored by an agency of the United States Government. Neither the United States Government nor any agency Thereof, nor any of their employees, makes any warranty, express or implied, or assumes any legal liability or responsibility for the accuracy, completeness, or usefulness of any information, apparatus, product, or process disclosed, or represents that its use would not infringe privately owned rights. Reference herein to any specific commercial product, process, or service by trade name, trademark, manufacturer, or otherwise does not necessarily constitute or imply its endorsement, recommendation, or favoring by the United States Government or any agency thereof. The views and opinions of authors expressed herein do not necessarily state or reflect those of the United States Government or any agency thereof. 


\section{DISCLAIMER}

Portions of this document may be illegible in electronic image products. Images are produced from the best available original document. 
Reference to a company or product name does not imply approval or recommendation of the product by Union Carbide Corporation or the U.S. Atomic Energy Commission to the exclusion of others that may meet specifications.

Printed in the United States of America. Available from

National Technical Information Service

U.S. Department of Commerce

5285 Port Royal Road, Springfield, Virginia 22151

Price: Printed Copy \$4.00; Microfiche $\$ 0.95$

This report was prepared as an account of work sponsored by the United States Government. Neither the United States nor the United States Atomic Energy Commission, nor any of their employees, nor any of their contractors, subcontractors, or their employees, makes any warranty, express or implied, or assumes any legal liability or responsibility for the accuracy, completeness or usefulness of any information, apparatus, product or process disclosed, or represents that its use would not infringe privately owned rights. 


\section{LENGTH AND STRAIN-RATE EFFECTS ON THE PROBABILITY OF FAILURE OF TWO BORON REINFORCING MONOFILAMENTS}

R. E. Oakes, Jr

Oak Ridge Y.12 Plant

P.O. Box Y. Oak Ridge, Tennessee 37830

Date Issued - October 29, 1973

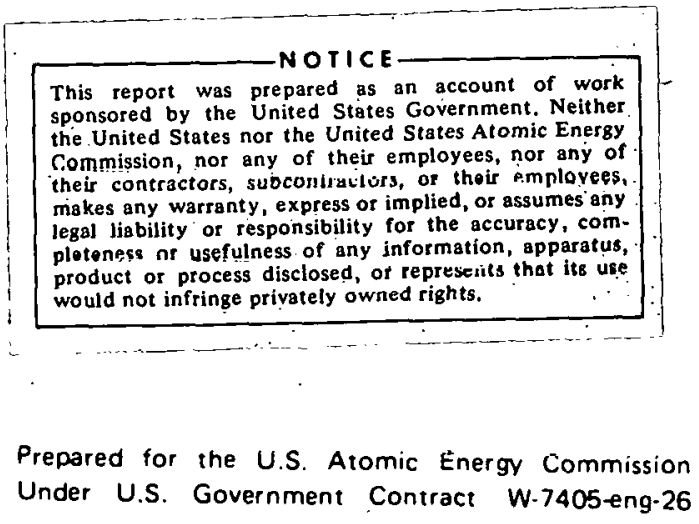




\begin{abstract}
Breaking-strength data from one-inch $(2.5-\mathrm{cm})$ gage-length specimens and Weibull statistical techniques are used to characterize the probability of failure dependence on the length of brittle tungsten-core and carbon-core boron monofilaments. Experimental results, using longer-gage-section specimens, are in good agreement with the failure probability predicted by the Weibull function. Strain-rate effects on the probability of failure of both materials are investigated over the quasistatic range from $3.3 \times 10^{-5}$ to $3.3 \times 10^{1} \mathrm{sec}^{-1}$. Failure probability is shown to be independent of the strain rate for both materials.
\end{abstract}




\section{CONTENTS}

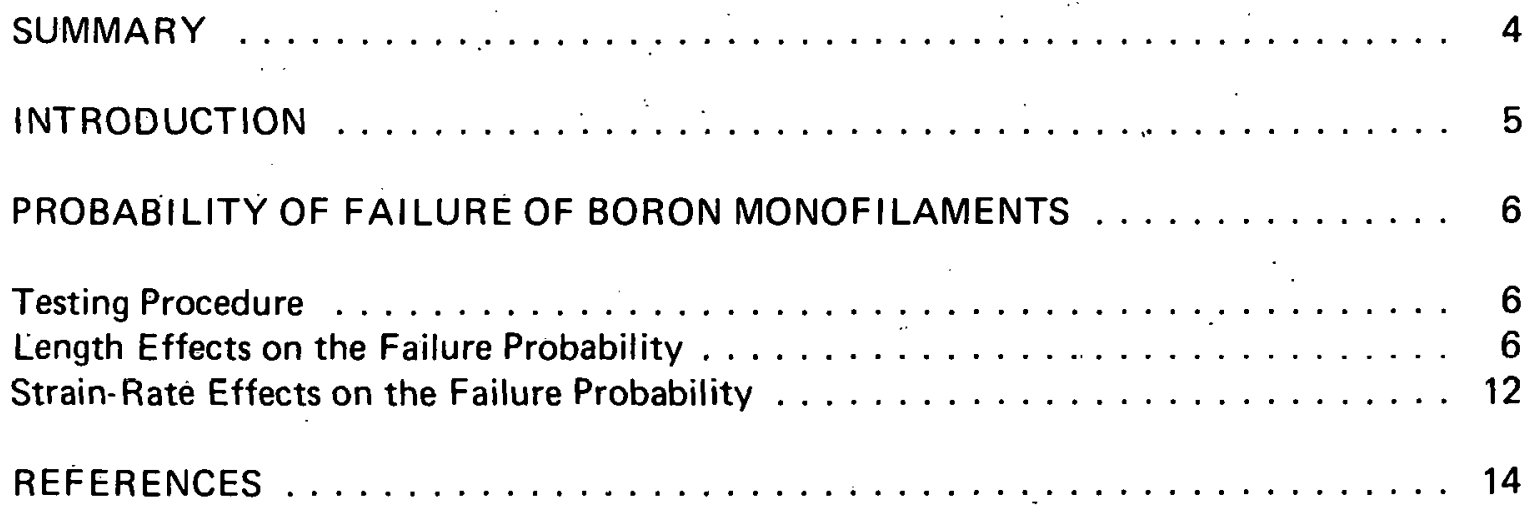




\section{SUMMARY}

Conventional test and data analysis methods are inadequate for characterizing the strength of brittle boron monofilaments presently in use as composite reinforcement materials. A nondegrading test method is suggested. Weibull statistical techniques are used to analyze the results, and characterization of strength is given in terms of the length dependence of the probability of failure. Experimental results on vapor-deposited tungsten-core and carbon-core boron monofilaments demonstrate the test and analysis procedure.

Effects of strain rate on the probability of failure are also investigated over the quasistatic range from $3.3 \times 10^{-5}$ to $3.3 \times 10^{1} \mathrm{sec}^{-1}$. Failure probability is shown to be independent of the strain rate for both materials. 


\section{INTRODUCTION}

Characterization of composite material components is a prerequisite to composite design. Characterization methods applicable to many materials are not applicable to vapor-deposited boron monofilaments and similar materials which fail in a brittle manner. Comparison of properties of such materials can be made only when proper test and analysis procedures are used.

The object of this work, performed at the Oak Ridge Y-12 Plant, (a) is threefold: First, is to suggest a practical. test procedure which does not degrade the filament by introducing significant stress concentrations at the grip location. Second, to outline a procedure to be followed for analyzing boron filament strength data. (The procedure which is suggested accounts for both the strength variation within a given gage length and the decreasing survival probability with increasing gage length, a characteristic of brittle materials.) Third, to evaluate the effect of strain rate on the failure probability of the brittle boron monofilaments using the recommended procedures. (Investigations of this effect are limited to the quasistatic strain-rate range-the range over which wave effects in the material are negligible.)

These three objectives are demonstrated at room temperature on nominal four-mil $(0.1-\mathrm{mm})$-diameter tungsten-core boron (Borsic) $(\mathrm{b})$ and the newer carbon-core $(\mathrm{c})$ boron filament materials. A spool of each material was randomly selected only for the purpose of demonstration and does not necessarily represent the best presently available. Experience gained in the manufacturing process is continuously improving the quality of boron monofilaments. It is intended that this report will provide guidance in the work of evaluating the mechanical properties of the other brittle reinforcing materials and in evaluating progress in the field of boron technology.

(a) Operated by the Union Carbide Corporation's Nuclear Division for the US Atomic Energy Commission.

(b) Product of the Hamilton Standard Division of United Aircraft Corporation.

(c) Product of the Avco Corporation. 


\section{PROBABILITY OF FAILURE OF BORON MONOFILAMENTS}

\section{TESTING PROCEDURE}

Specimen degradation, caused by stress concentrations at the grip location, is evident when specimen failures consistently occur at the grip/specimen interface. Such failures bias results by greatly reducing the apparent tensile strength of individual specimens. Grip damage is avoided in this work by using a grip design and specimen-preparation technique previously proved satisfactory in an extensometer design. (1)

Briefly, this technique for minimizing grip stress concentrations was accomplished by clamping indirectly to the specimen. The specimen ends are inserted into small (25-gage) disposable hypodermic needles, leaving the desired gage length exposed between the two needle ends. A thin epoxy (ten parts Shell Epon 815 to one part TETA hardener) is then extruded from a syringe through the needle and around the specimen until a small bead of the epoxy forms at the needle tip. (This bead protects the specimen from the sharp needle edges.) After the epoxy hardens, load is transmitted to the specimen through the needle and epoxy. This preparation and test procedure is economical enough to permit a large number of specimens to be tested and proved effective in eliminating grip failures.

\section{LENGTH EFFECTS ON THE FAILURE PROBABILITY}

To define the tensile-strength distributions of the two boron-filament types, 100 strength observations were made on each material using one-inch $(2.5-\mathrm{cm})$ gage-section specimens. These tests were made at a strain rate of $3.3 \times 10^{-5} \mathrm{sec}^{-1}$. Failure frequency histograms of. the two boron filament types, tungsten core and carbon core, are presented in Figures 1 and 2. Cumulative failure frequency plots on normal probability scales (Figures 3 and 4 ) of these data are nearly linear; indicating that, for a given specimen length, both materials can be approximated by a Gaussian or normal distribution.

The volume of material under stress (in this case, the specimen gage length) influences the brittle material strength test results. Increasing the volume of material under stress increases the probability of the presence of a severe stress-intensifying flaw. In the absence of plasticity, this stress concentration cannot be relieved, so fracture occurs. Since a failure at any location in the specimen results in total specimen failure, low-strength failures are more likely in long specimens. An "average strength value" for such materials does not suffice. Probability of failure must be specified in terms of the amount of material under stress. The normal distributions, such as Figures 1 and 2, do not adequately define the material strength.

The empirical distribution function proposed by Weibull(2) is generally accepted as being the most applicable statistical function for describing strength distributions of brittle materials. Armenákas, et al ${ }^{(3)}$ have shown that Weibull parameters of the reinforcement material can be used in the statistical theories of bundle and composite material strengths.

Herring ${ }^{(4)}$ has demonstrated a simple constant evaluation technique for the Weibull function. This function can be written as:

$$
P=1-e^{-L}\left(\frac{\sigma-\sigma_{u}}{\sigma_{0}}\right)^{m}
$$




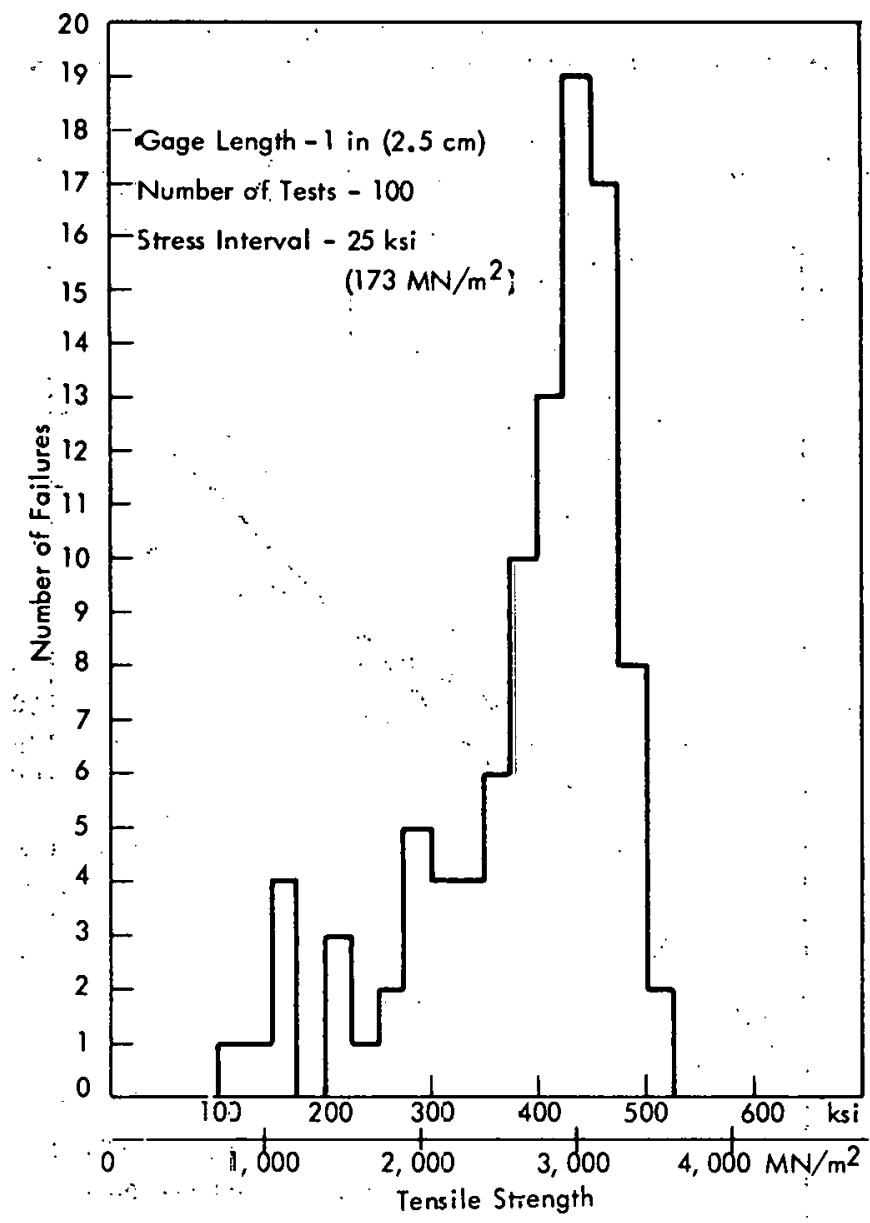

Figure 1. FREQUENCY HISTOGRAN OF TENSILE FAILURES OF TUNGSTEN:CORE BORON MONOFILAMENTS:

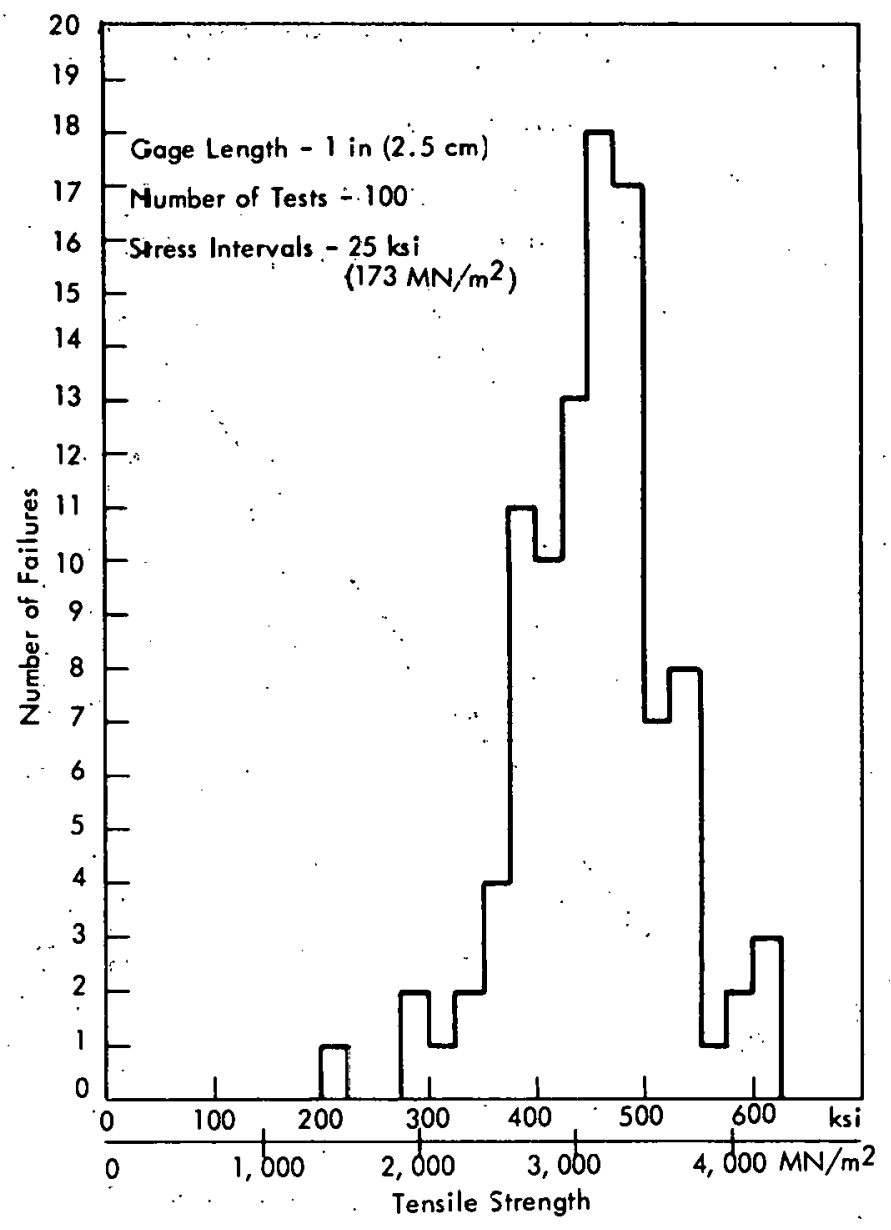

Figure 2. FREQUENCY HISTOGRAM OF TENSILE FAILURES OF CARBON-CORE BORON MONOFILAMENTS. 


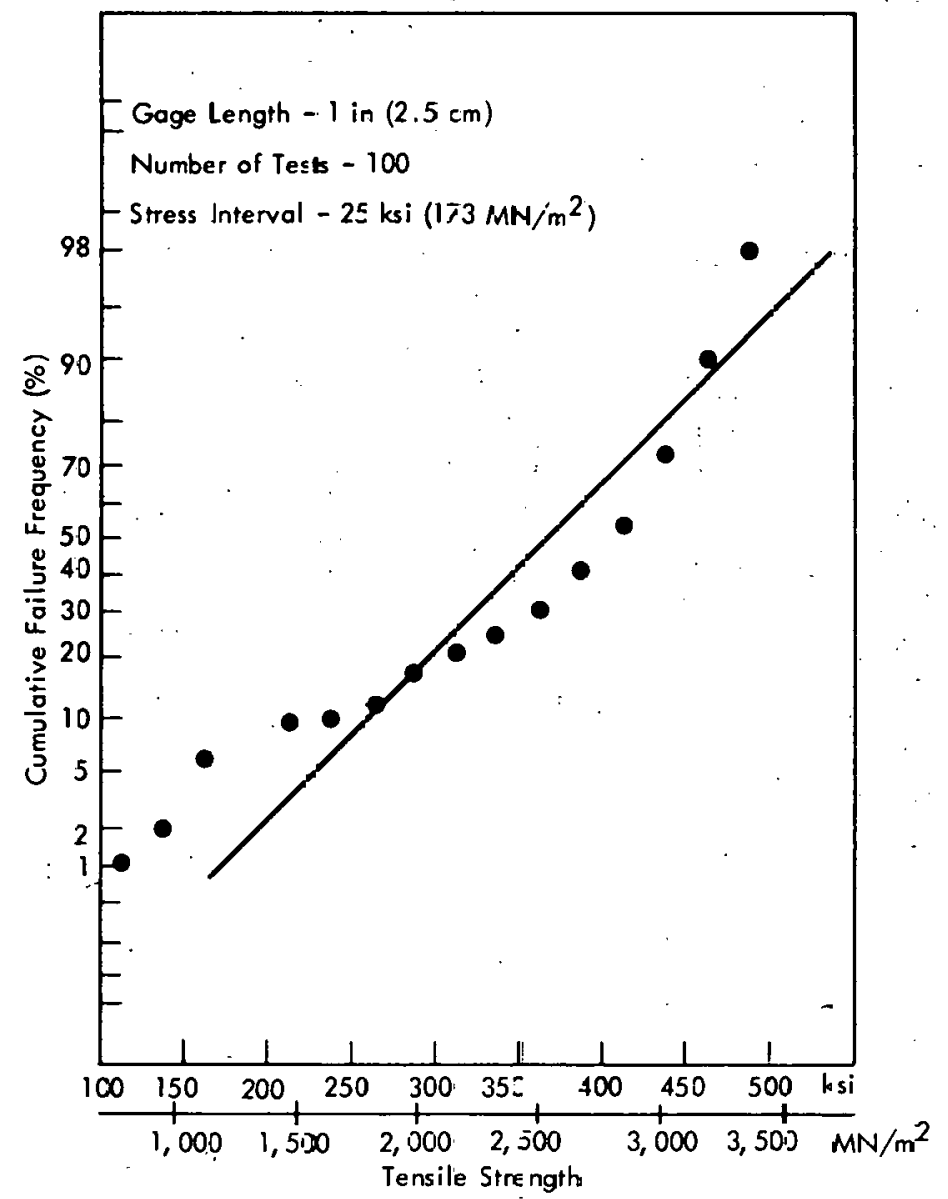

Figure 3. CUMULATIVE FAILIJRE FREQUENCY PLOT F.JR TUNGSTEN-CORE BORON MONOFILAMENTS.

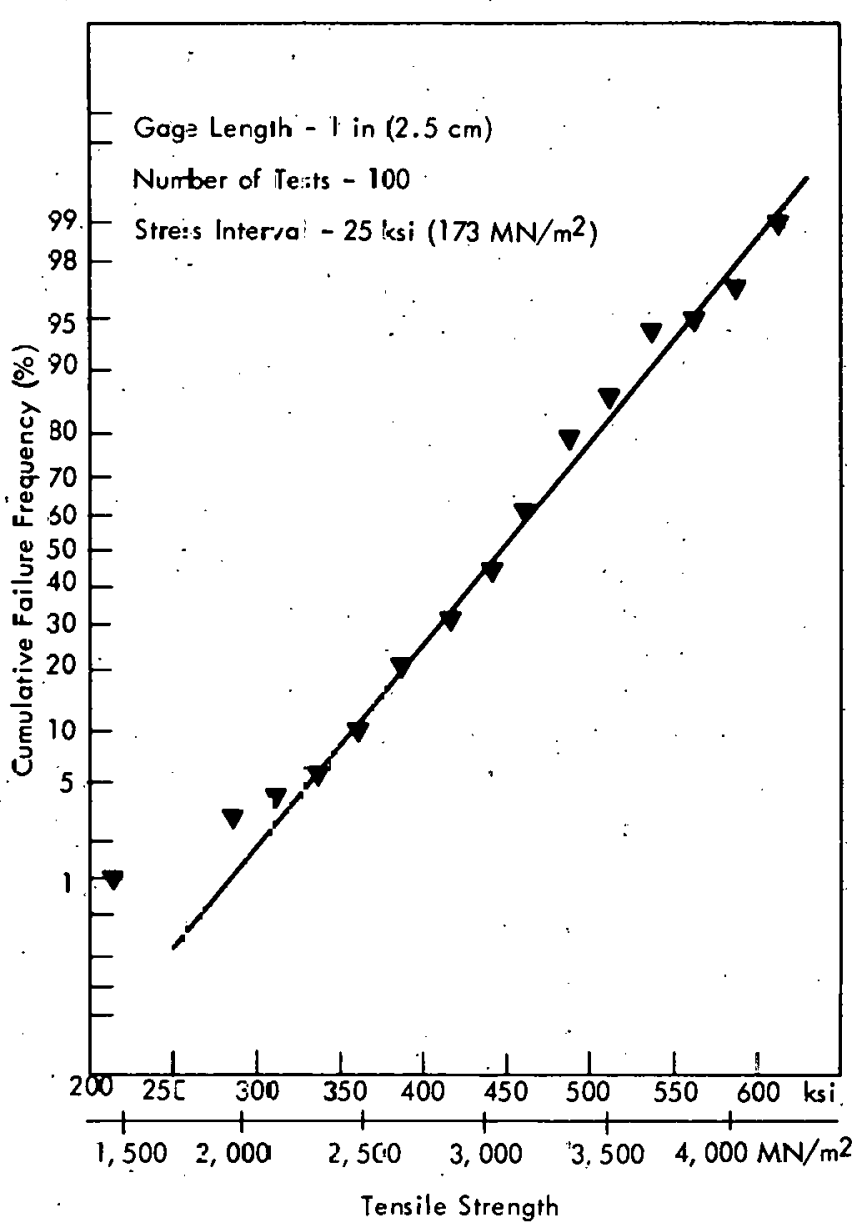

Figure 4. CUMULATINe FAILURE FREQUENCY PLOT FOR CARBON-COZE BORCN MONOFILAMENTS. 
where:

P represents the probability of specimen failure,

e the base of the natural logarithm,

$L \quad$ the filament gage length,

$\sigma$ the filament tensile strength,

$\sigma_{\mathrm{u}} \quad$ the value of $\sigma$ for which $\mathrm{P}=0$,

m the shape factor for the distribution, and

$\sigma_{0} \quad$ the scale factor for the distribution.

Rearranging Equation 1 and taking the logarithm of both sides twice gives:

$$
\ln \left[\ln \left(\frac{1}{1-P}\right)\right]=m\left[\ln \left(\sigma-\sigma_{u}\right)-\ln \sigma_{0}\right]+\ln \mathrm{L} \text {, }
$$

which is a more useful form for evaluating the Weibull parameters $m, \sigma_{u}$, and $\sigma_{0}$ for each material.

Evaluation of constants is done in four steps:

1. Corresponding values of $P$ and $\sigma$ from the normal distribution plots, Figures 3 and 4 , are substituted into Equation 2.

2. Plots are constructed of $\ln \ln \left(\frac{1}{1-P}\right)$ versus $\ln \left(\sigma-\sigma_{\mathrm{u}}\right)$ for assumed values of $\sigma_{\mathrm{u}}$. The correct value for $\sigma_{\mathrm{u}}$ results in a linear plot. Figures 5 and 6 are plots for various assumed values of $\sigma_{\mathrm{U}}$.

3. The shape factor, $m$, is determined from the slope of the straight line obtained from the previous step.

4. The scale factor, $\sigma_{\mathrm{U}}$, is then calculated for each material by direct substitution into Equation 2.

Constants $\sigma_{\mathrm{u}}, \mathrm{m}$, and $\sigma_{\mathrm{O}}$, thus obtained, are given for both materials in Table 1 .

Characterization of the brittle materials in terms of specimen gage length and failure probability requires only these length-independent constants and Equation 1. Using these constants and Equation 1, failure probability levels of 1, 50, and 99 percent are plotted as a function of length in Figures 7 and 8 . Most failures of longer specimens are expected to fall above the 1 percent and below the 99 percent probability levels, while the average value of a group of tests is expected to follow the $\mathbf{5 0}$ percent probability curve. To verify the theory, additional data were taken on longer gage-length specimens for comparison with these predicted failure probability levels. Gage lengths of $2.5,5,10$, and 25 


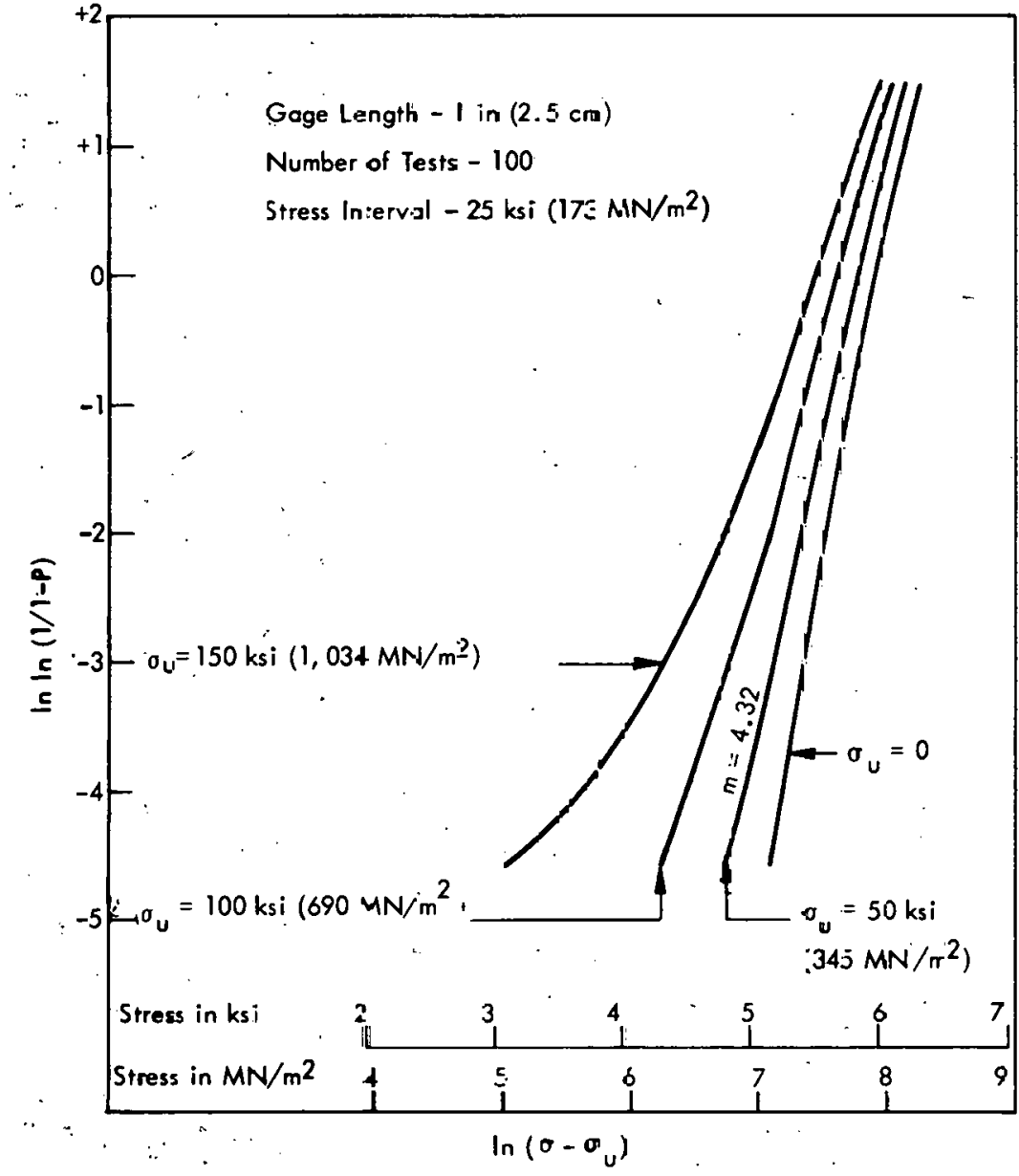

Figure 5. WEIBULL DISTRIBU $=$ ION PARAMETERS FOR TUJUSTEN.CORE BORON MONOFILAMENTS.

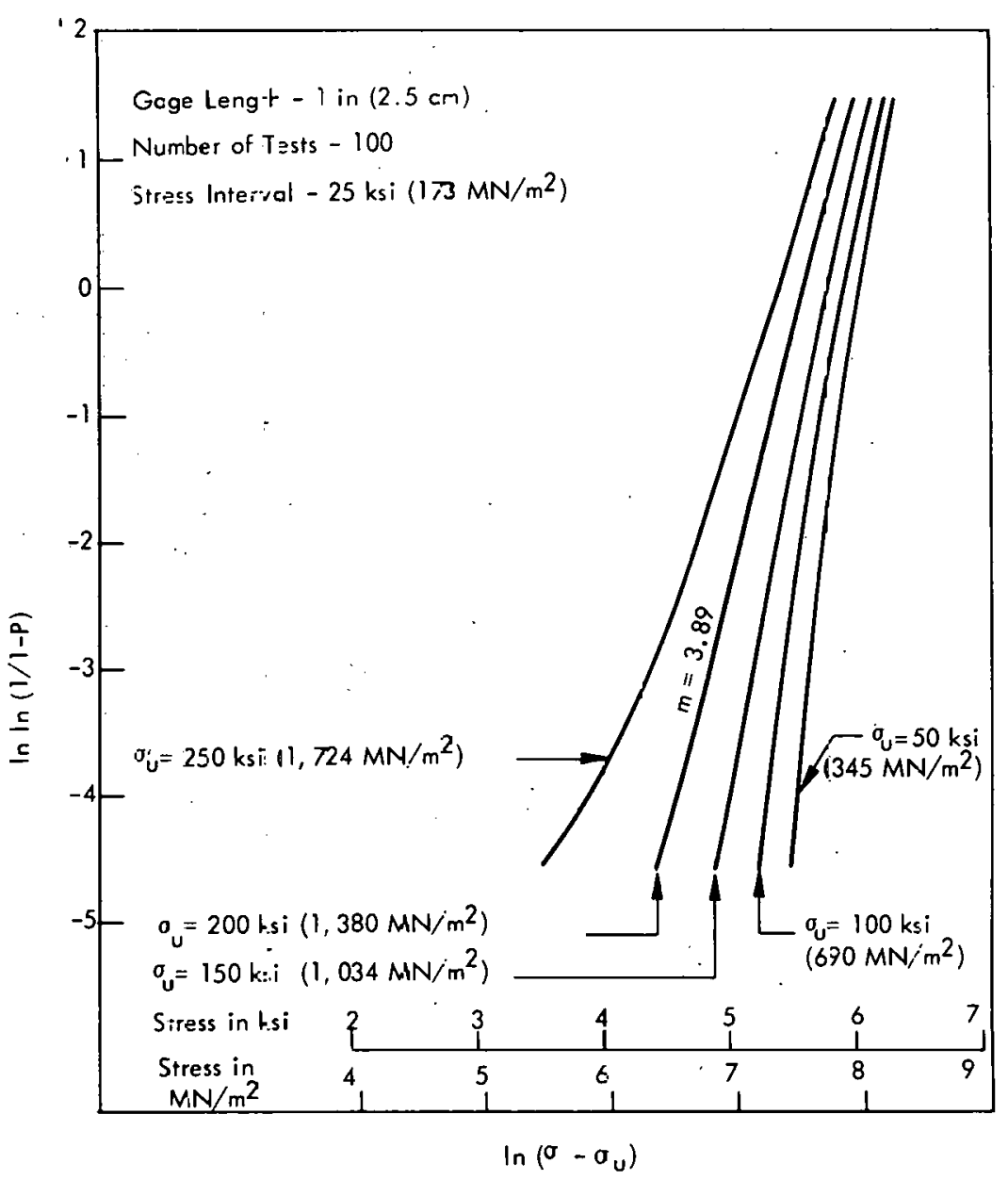

Figure 6. WEIBULL DISTRIBUTION PARAMETERS FOR CARBON-CORE BORON MONOFILAAIENTS. 
Table 1

EXPERIMENTALLY DETERMINED WEIBULL DISTRIBUTION CONSTANTS FOR BORON MONOFILAMENTS

\begin{tabular}{cccc}
\hline Material & $\begin{array}{c}\text { Lower Bound, } o_{u} \\
\text { ksi }\left(G N / \mathrm{m}^{2}\right)\end{array}$ & Shape Factor, $\mathrm{m}$ & $\begin{array}{c}\text { Scale Factor, } \sigma_{\mathrm{O}} \\
\text { ksi }\left(\mathrm{GN} / \mathrm{m}^{2}\right)\end{array}$ \\
\hline Tungsten Core & $50(0.345)$ & 4.32 & $343(2.37)$ \\
Carbon Core & $200(1.38)$ & 3.89 & $269(1.86)$ \\
\hline
\end{tabular}

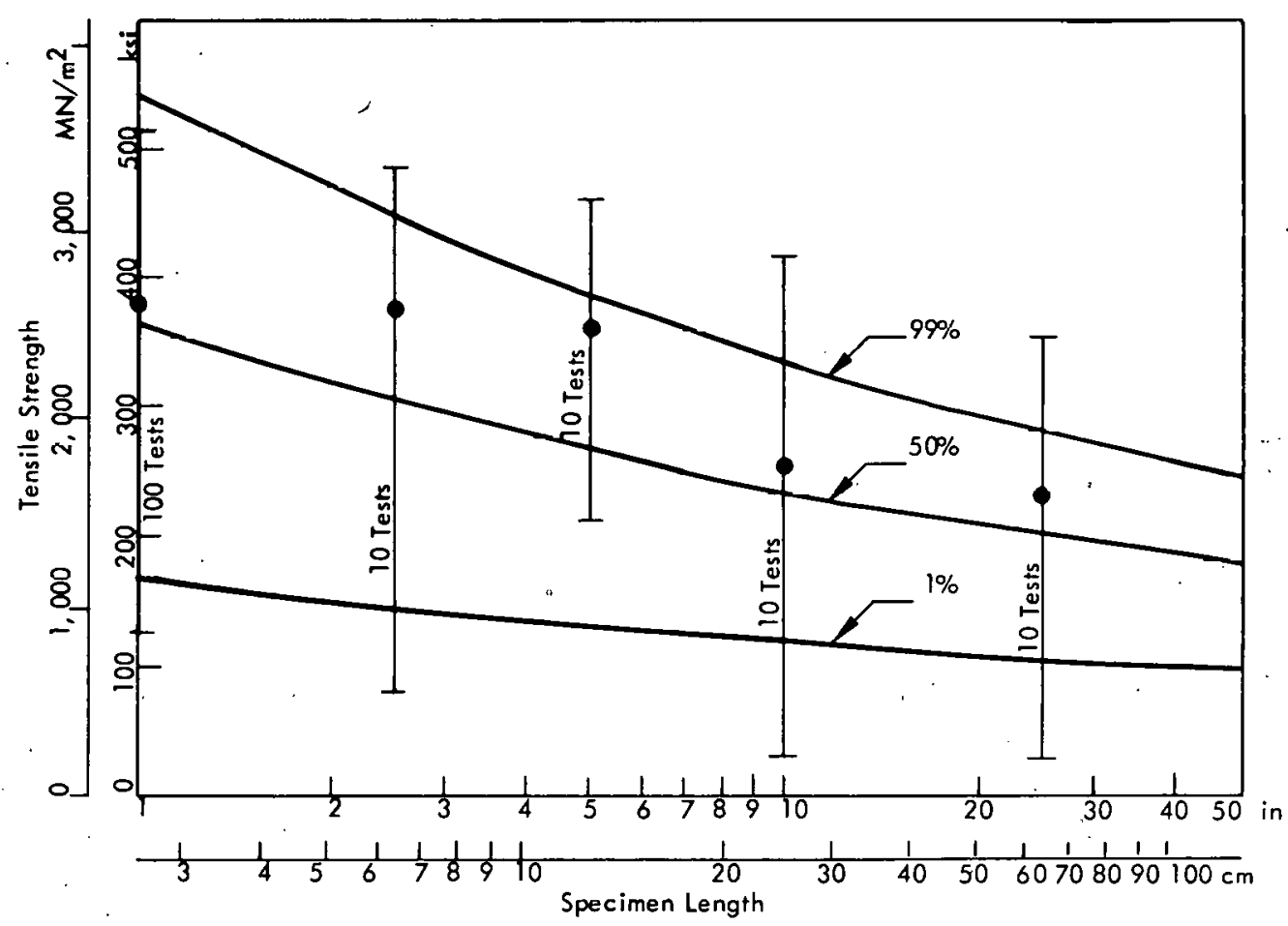

Figure 7: TENSILE STRENGTH AS A FUNCTION OF THE GAGE LENGTH FOR TUNGSTEN-CORE BORON MONOFILAMENTS. $\left(\dot{\epsilon}=3.3 \times 10^{-5} \mathrm{sec}^{-1}\right)$

inches $(6.4,12.7,25.4$, and $63.5 \mathrm{~cm})$, corresponding to available testing machine crosshead velocity increases, were chosen so as to maintain a single strain rate of $3.3 \times 10^{-5} \mathrm{sec}^{-1}$. This provision precludes bias from rate effects (investigated later). The average value of ten tests per length and the üpper and lower limits of the observed failures are given in Figures 7 and 8. Reasonable agreement between theory and experiment is noted for both materials. A significant number of very-low-strength failures is observed in the one-inch $(2.5-\mathrm{cm})$ gage-length tests of the tungsten-core material. (Compare the low-strength breaks in Figure 1 with the low-strength breaks in Figure 2.) Due to these low-strength results, the tungsten-core distribution for the one-inch $(2.5-\mathrm{cm})$ specimens deviates from the normal probability function more than the carbon-core material. Probability-strength correlations for the Weibull function, taken from this normal distribution (Step 1), are not as good as for the carbon-core data. 


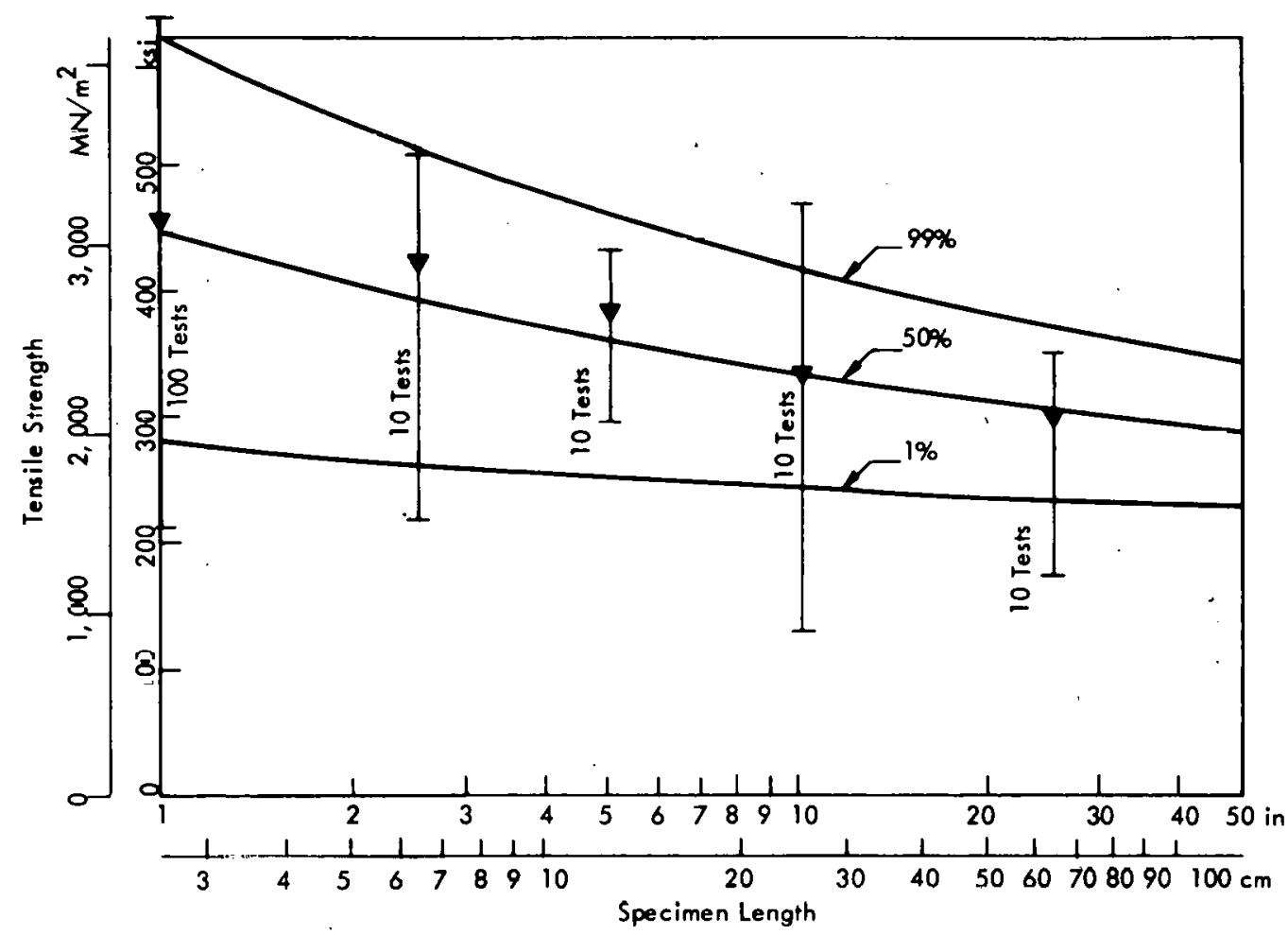

Figure 8. TENSILE STRENGTH AS A FUNCTION OF THE GAGE LENGTH FOR CARBON-CORE BORON MONOFILAMENTS. $\left(\dot{\epsilon}=3.3 \times 10^{-5} \mathrm{sec}^{-1}\right)$

\section{STRAIN-RATE EFFECTS ON THE FAILURE PROBABILITY}

To evaluate strain-rate effects on the failure probability of boron filaments, one-inch $(2.5-\mathrm{cm})$ gage-length specimens of both material types were tested in decade increments of strain rate over the quasistatic range from $3.3 \times 10^{-5}$ thruugl $3.3 \times 10^{1} \mathrm{sec}^{-1}$. The upper

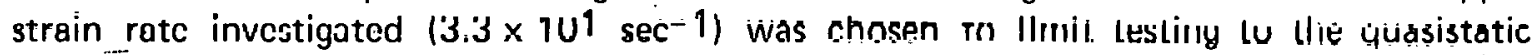
range-the range over which stress-wave effects are insignificant. In this range, stress equilibrium exists throughout the specimen length; so, conventional high-response force-measuring instrumentation was used. At the maximum strain rate, errors introduced by wave effects $(5)$ are calculated to be no greater than one percent.

The average upper and lower limits of experimental values from ten tests are reported in Figures 9 and 10. Also plotted in these figures are the 1 percent and 99 percent probability-of-failure values for one-inch $(2.5-\mathrm{cm})$ specimens at $3.3 \times 10^{-5} \mathrm{sec}^{-1}$. Most higher rate failures fell within the bounds established for the $3.3 \times 10^{-5} \mathrm{sec}^{-1}$ tests. Thus, for design purposes, the probability of failure of these filaments can be considered rate independent over the range investigated. 


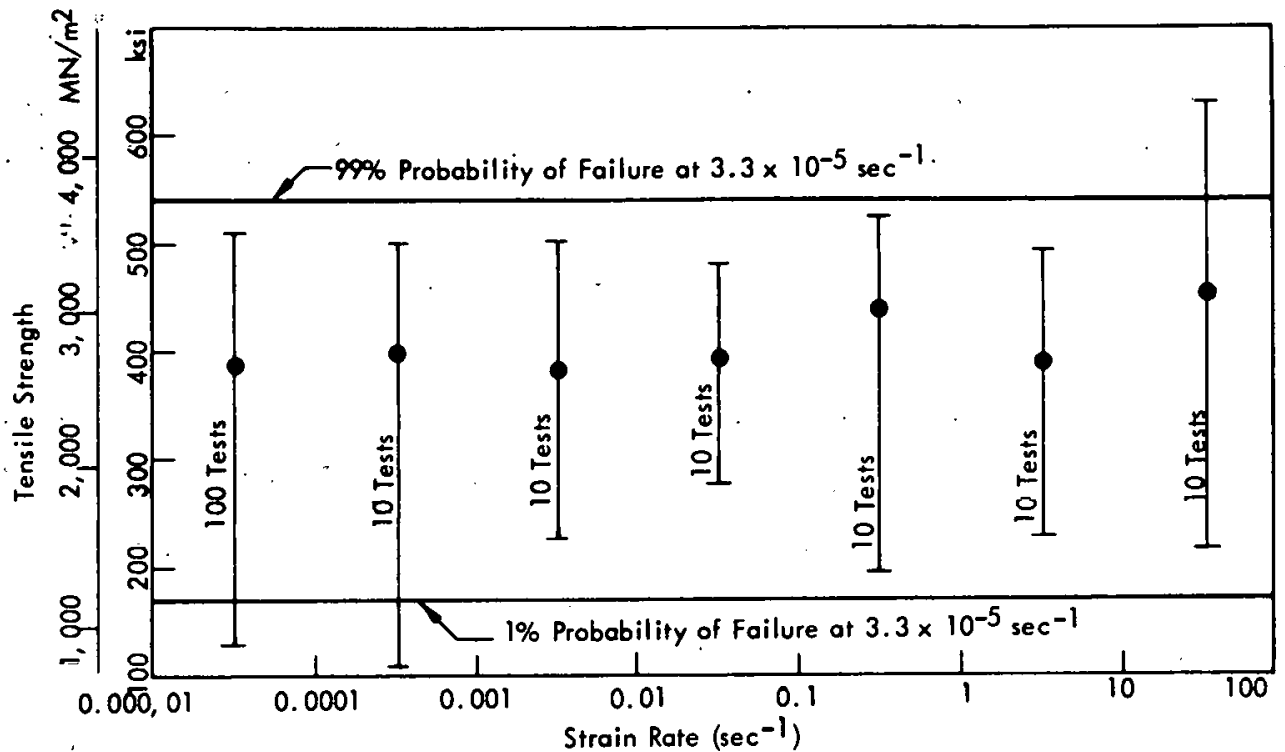

Figure 9. TENSILE STRENGTH AS A FUNCTION OF THE STRAIN RATE FOR TUNGSTEN-CORE BORON MONOFILAMENTS. (Gage Length $=1$ inch or $2.5 \mathrm{cms}$ )

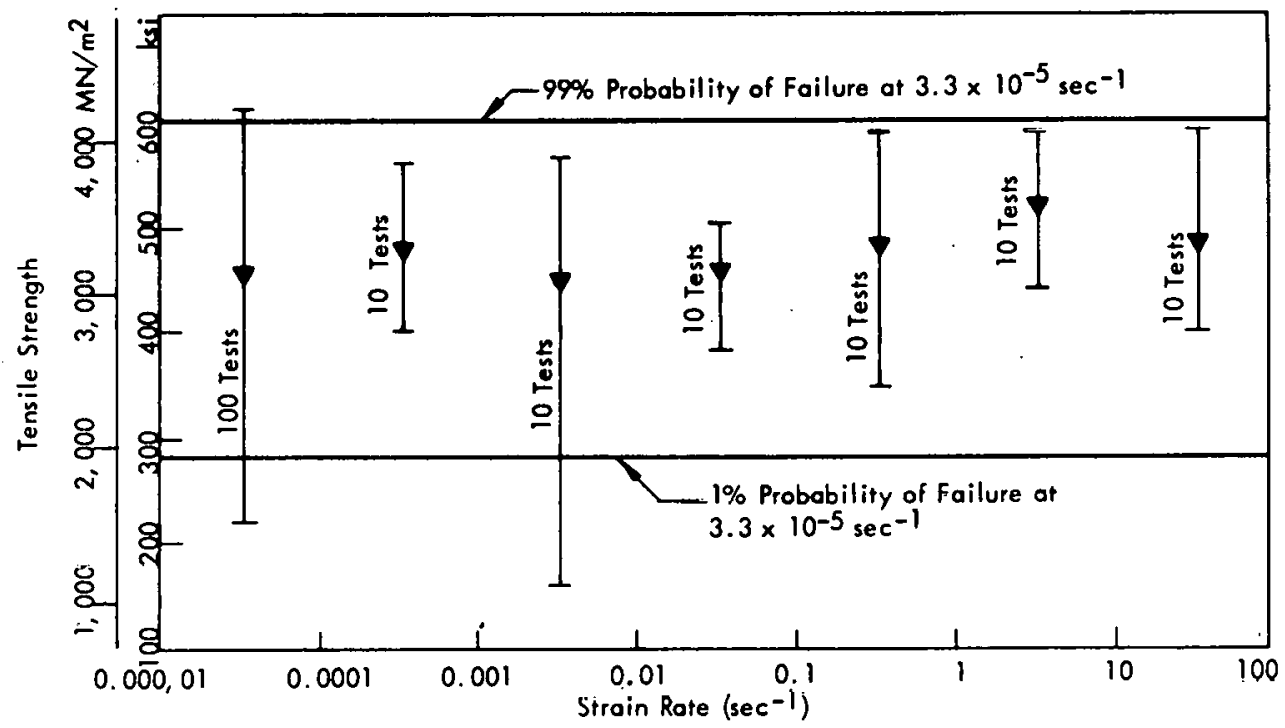

Figure 10. TENSILE STRENGTH AS A FUNCTION OF THE STRAIN RATE FOR CARBON-CORE BORON MONOFILAMENTS. (Gage Length $=1$ inch or $2.5 \mathrm{cms}$ ) 


\section{REFERENCES}

(1) Oakes, R. E., Jr; An Improved Extensometer for Determining the Mechanical Properties of Fine Wires and Filaments, Y-DA-4756; Union Carbide Coporation-Nuclear Division, Oak Ridge Y-12 Plant, Oak Ridge, Tennessee; May 12, 1972.

(2) Weibull, W.; "A Statistical Distribution Function of Wide Applicability", J App/ Mech, 18, (3), pp 293-297; September 1951.

(3) Armenákas, A. E., Garg, S. K., Sciammarella, C. A., and Svalbonas, V.; "Experimental Study of the Failure Mechanism and Strength Characteristics of Fiber. Bundles and Composites", Experimental Mechanics, 12, (1), pp 1-10; January 1972.

(4) Herring, H.W.; Selected Mechanical and Physical Properties of Boron Filaments, NASA-TN-D-3202; Langley Research Center, Hampton, Virginia (1966).

(5) Armenákas, A. E. , Garg, S. K., and Sciammarella, C. A.; "Strength Characteristics of Glass Fibui's Under Dynomio Loading", Journal of Appilied Phrssics, 41 , (1), pp 1657-1664; March 1970. 


\section{DISTRIBUTION}

Atomic Energy Commission - ORO

Hickmán, H:D.

Zachry, D.S., Jr

Lawrence Livermore Laboratory

Engle, R.B.

Tatro, C.A.

Weiss, H.D.

Los Alamos Scientific Laboratory

Eash, J.E.

Hockett, J.E.

Olwin, R.B.

Skaggs, R.

Taub, J.M.

Oak Ridge Gaseous Diffision Plant

Arendt, J.W.

Blake, H. W.

Douglass, T.E.

Keyser, R.M.

Steakley, M.F.

Waters, D.A.

Wilcox, W.J., Jr

Winkel, R.A.

Oak Ridge Y-12 Plant

Alvey, H.E.

Banker, J.G.

Bernander, N.K.

Briscoe, O.W.

Burditt, R.B.

Burkhart, L.E.

Cadden, J.L.

Denny, A.

Dritt, W.S.

Ellingson, R.D.

Foulk, D.L.

Hulsey; W.J:

Jackson; V.C.

Jones, F.W. 
Kahl, K.G.

\section{Sandia-Livermore}

Keith, Alvin

Kite, H.T.

Knight, C.E.

Meinken, R.H.

Knowles, C.M.

Mote, M.W.

Long, P.J.

Lundin, M.I.

Mason, D.L.

McLendon, J.D.

Mitchel, G.W.

Moyer, M.W.

Myhre, T.C.

Napier, J.M.

Oakes, R.E., Jr (10)

Olipliarıl, G.W.

Poorc, M:W.

Reeves, C.A.

Sinith; J.H.

Smith, R.D.

Stoner, H.H.

Telford, J.L.

Weathersby, W.E.

Whitson, W.K.

Yaggi, W.J.

Y-12 Central Files (5)

$Y-12$ Central Files (master copy)

$Y-12$ Central Files (route)

Y-12 Central Files (Y-12RC)

Paducah Gaseous Diffusion Plant

Levin, R.W.

\section{Sandia-Albuquerque}

Albright, C.E

Allred, R.E.

Hoover, W.R.

Zimmerman, J.C.

In addition, this document is distributed in accordance with the category UC-25, Materials, as given in the USAEC Standard Distribution. Lists for Unclassified Scientific and Technical Reports, TID-4500. 